\title{
Smart Tourism Cities' Competitiveness Index: A Conceptual Model
}

\author{
Namho Chung ${ }^{1}$ (D), Hyunae Lee ${ }^{2}$ (D), Juyeon Ham $^{2}$ (D), \\ and Chulmo $\mathrm{Koo}^{1(\bowtie)}(\mathrm{D}$ \\ ${ }^{1}$ Smart Tourism Education Platform, Kyung Hee University, \\ Seoul, Republic of Korea \\ \{nhchung, helmetgu\}@khu.ac.kr \\ ${ }^{2}$ Smart Tourism Research Center, Kyung Hee University, \\ Seoul, Republic of Korea \\ \{halee8601, juyeon.ham\}@khu.ac.kr
}

\begin{abstract}
As smart tourism cities are becoming a blur boundary between residents and tourists at a spatial place (e.g., urban city or destination), innovation and technologies should be integrated with tourism applications and urban infrastructure. The idea of smart tourism cities is generated as incorporating tourism business or tourism context into everyday life, opening up opportunities in daily life and travel. We need to explore a possible concept of smart tourism cities and how urban cities can play a role of the duality emphasizing on the blurring boundaries and allowing both residents and travelers to co-create the value of the urban cities' competitiveness name as 'smart tourism cities.' This study aims to develop a competitiveness evaluation index for sustaining urban cities through tourism.
\end{abstract}

Keywords: Smart tourism cities $\cdot$ Competitiveness index $\cdot$ Urban cities $\cdot$ Smart cities $\cdot$ Smart tourism $\cdot$ Evaluation

\section{Introduction}

In recent years, the global prevalence of smart technologies and devices has fundamentally changed the way of global urban cities are constructed, consumed and shared between visitors and residents, as well as mediated by technologies and tourism businesses. Tourists in urban cities are usually playing a variety of memorable tourism experiences during their local traveling. Travel activities such as accommodating, dining at a restaurant, shopping and entertaining are all taking place at urban cities that are called as tourism destinations [1]. In this way, tourists or visitors consume resources and infrastructure of the city that are all providing for citizens and residents.

How can the urban cities make a blended place of life and travel in spatial alike? Google Maps, mobility (e.g., Uber), and accommodations (e.g., Airbnb) play an

This paper was supported by Seoul Tourism Organization and was supported by the Ministry of Education of the Republic of Korea and the National Research Foundation of Korea (NRF2019S1A3A2098438). 
essential role in making a city smarter and more accessible to people, which enable the blending of tourists and residents and foster the conversion of regular homes or cars into tourism and hospitality offerings. In order to enhance the smart tourism experience [2], urban functions, facilities, amenities, infrastructure of the cities can intertwine seamlessly urban life and needs of tourism in smart cities [3]. Therefore, it is necessary to have a guideline of how tourism context and urban life are overlapped in smart cities, and maximize smart tourism through effective and efficient use of the urban infrastructure and functions [4]. Therefore, last but not least, we try to conceptualize smart tourism perspective into smart city as one place that are blurred for both of residents and tourists $[1,4]$ and provide an index from which broader views of smart tourism and cities competitiveness [5] that can evaluate relatively smart tourism cities and measure its resources, capabilities, management, and policies.

\section{Literature Review}

\subsection{Smart Tourism and Urban Competitiveness}

Smart tourism can refer to tourism that is technologically, economically and socially developed or growing by advanced smart technologies [2]. Gretzel et al. [2] conceptualized smart tourism as technological oriented on-site tourism experience at a destination. Meanwhile, the concepts of smart city are generating various definitions, including intelligent city, digital city, and ubiquitous city (U-city) [6]. Smart city is defined as a city equipped with ICT infrastructure to lead social and urban growth through reinforcement of economic level, citizens' participation and government efficiency [7]. Celino and Kotoulas regarded smart city as an urban ecosystem that utilize connected technologies to improve urban operations and make intelligent near real-time decision [8]. Isi lab addressed how smart city helps to resolve numerous urban problems as well as how advanced technologies implement into urban infrastructure [6]. To sum up, the attributes of smart city which commonly mentioned in these definitions are (1) connectivity through ICTs (2) efficiency improvement (3) sustainability (4) ecofriendliness (5) improved quality of life. We regarded smart tourism city as a combination of smart tourism and smart city. In smart tourism destination, automated tourism services and creative contents that induce tourists' desire are development. For tourism context, smart city can be defined as "a city using technologies innovatively to achieve resource optimization, effective and fair governance, sustainability and quality of life" [2, p. 179]. In this perspective, smart tourism cities are "an innovative tourist destination that guarantees sustainable development that facilitates and enhances visitors' interaction with experiences at the destination and eventually improves the residents' quality of life" [9, p. 6], and it has been regarded as a solution to various problems facing various smart cities (e.g., over-tourism). 


\subsection{Competitiveness Index for Smart Tourism Cities}

In the tourism field, the World Economic Forum (WEF) mainly evaluates tourism competitiveness (e.g., [10]), but it is insufficient to evaluate the smart tourism cities as it focuses on general tourism rather than, specifically, smart tourism. WEF's indicators only take into account ICT readiness, which focuses on building and using ICT infrastructure such as mobile and internet. However, considering the concept of smart tourism, developing various indicators that can enable smart tourism that maximizes the tourist's experience on-site from the viewpoint of smartization as a whole are required. Regarding smart tourism cities, the European Union (EU) has been conducting a project to support promotion and marketing activities of the city by evaluating the excellent smart tourism capitals in the EU every year. The evaluation area is largely divided into four areas: Accessibility, Sustainability, Digitalization and Cultural Heritage and Creativity [11]. However, considering the concept of smart tourism cities, first, the evaluation indices of the EU focus more on the point of view of tourists, and therefore, it lacks consideration of the various social issues experienced by residents due to tourism. In particular, smart tourism cities should consider sustainable development through symbiosis between citizens and tourists. Second, collaborative partnerships and building its ecosystems with various stakeholders related to smart tourism cities are also an important area that should be considered for building competitiveness of smart tourism cities, but the EU's indices lack consideration for these areas. Therefore, we believe that there should be a need for embracing evaluation indices and measurement items for smart tourism cities considering both smart tourism and smart cities' perspectives.

\section{Conceptual Framework}

Figure 1 illustrates the conceptual framework of this study. Based on the three components of smart tourism cities suggested by [2], the research frame work was comprised of three phases: smart destination, smart business ecosystem, and smart experience. First, smart experience in smart tourism cities is based on a concrete smart destination and business ecosystem [9]. Thus, smart destination can be categorized and assessed by four dimensions: attractiveness, sustainability, accessibility and digitalization readiness [11]. Again, these dimensions can be characterized into two aspects of smart tourism destination: tourism versus city. Secondly, smart business ecosystem is composed of numerous stakeholders who forms collaborative partnership with each other [5]. Finally, smart experience can be tourists' and residents' memorable experience enhanced by advanced ICT [6]. 


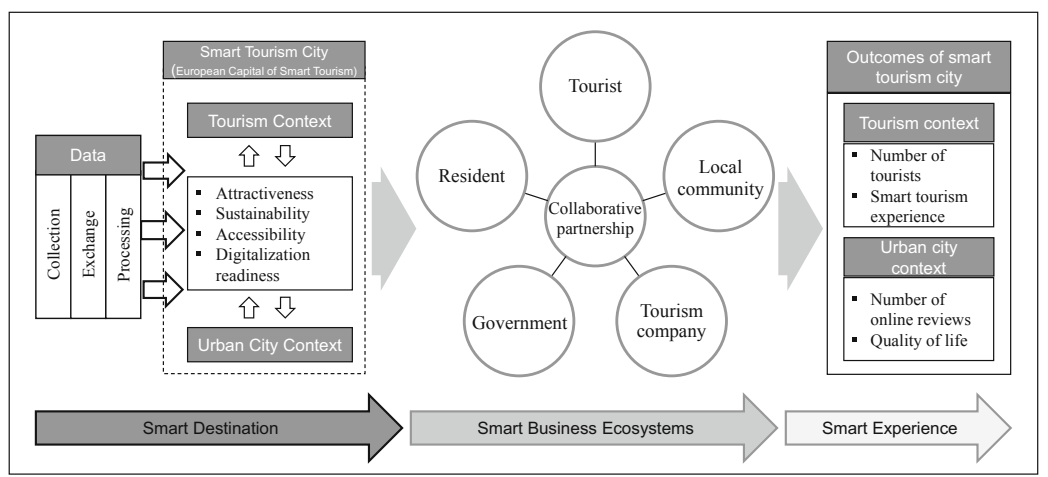

Fig. 1. Conceptual framework

\section{Smart Tourism Cities' Competitiveness Index}

After developing the first indicator based on the conceptual framework, we collected experts' opinion about that via Delphi survey for increasing objectivity and expertise. Delphi experts were composed of 12 experts in various field such as smart tourism, smart city and index development. Based on their opinions, we could develop the following smart tourism index comprised of 5 subcategories, 18 pillars and 48 individual indicators (see Fig. 2).

Based on the evaluation areas developed by EU [11] and results of Delphi survey, we defined the five subcategories as follows. Attractiveness is a degree to which tangible and intangible tourist attractions are provided through the Internet or ICTs. It is comprised of smart attraction, smart amenities, smart contents and online popularity. Accessibility is a degree to which touristic information and transportation system can be accessed by both of virtual and physical ways. It consists of smart convenience, smart mobility and barrier-free design. Digitalization readiness is a degree of data openness and infrastructure that can provide high-quality smart tourism information based on the cutting-edge ICTs. It is comprised of digital infrastructure, information openness, smart platform and smart service technology. Sustainability is a degree to which a smart tourism city has a foundation for sustainable social, economic and environmental growth. It is comprised of life and tourism environments, tourism creativity and innovativeness, tourism safety and city resilience. Finally, collaborative partnership is a degree of establishment of a smart tourism ecosystem for the symbiosis of numerous stakeholders in smart tourism cities. It consists of resident-tourist symbiosis, living lab activation and smart tourism governance. 


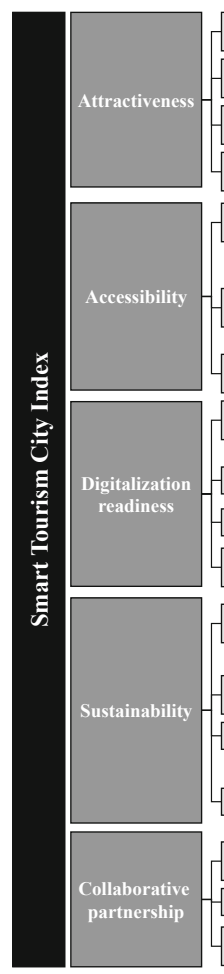

\begin{tabular}{|c|c|}
\hline Smart attraction & $\begin{array}{l}\text { - Number of (1) Google search results extracted for heritage and natural sites (2) VR attractions presented on } \\
\text { Tripadvisor }\end{array}$ \\
\hline Smart amenities & $\begin{array}{l}\text { - Number of (1) Airbnb listings (2) restaurants presented on Tripadvisor } \\
\text { - Percentage of hotels providing free wi-fi service on booking.com }\end{array}$ \\
\hline Smart contents & $\begin{array}{l}\text { - Number of (1) local cultural contents presented on Tripadvisor (2) Youtube channel subscribers and contents of } \\
\text { city (3) cultural activities on Airbnb }\end{array}$ \\
\hline Online popularity & $\begin{array}{l}\text { - Ranking of most instagrammable cities } \\
\text { - Three kinds of digital demand (accommodation, generic touristic information and touristic activities) }\end{array}$ \\
\hline Smart convenience & $\begin{array}{l}\text { - Number of (1) channels of ICT-based tourism information (2) languages served in DMO websites } \\
\text { - Presence of app to predict optimal route using public transportation information } \\
4 \text { questions for tourists' perceived quality of smart convenience (e.g. In city 'A', I can access to touristic } \\
\text { information by using my smartphone.) }\end{array}$ \\
\hline Smart mobility & \begin{tabular}{|l} 
- Number of shared bicycles per one million \\
- 3 questions for tourists' perceived quality of smart mobility (e.g. In city 'A', I can use a shared electronic \\
kickboard to go to any destination I want)
\end{tabular} \\
\hline Barrier-free design & $\begin{array}{l}\text { - Percentage of barrier-free hotels on presented on Booking.com } \\
\text { Number of barrier-free touristic services presented on DMO website }\end{array}$ \\
\hline Digital infrastructure & $\begin{array}{l}\text { - Number of free wi-fi hotspots per } 1 \mathrm{~km}^{2} \\
\text { - Q1: Please select every places you could use free wi-fi in city 'A'. } \\
\text { - Fixed broadband Internet speed of a country in which city 'A' is located } \\
\text { Smartphone penetration rates of a country in which city 'A' is located }\end{array}$ \\
\hline Information openness & - Number of (1) DB list managed by the integrated operation center (2) city-specific data open API offerings \\
\hline Smart platform & $\begin{array}{l}\text { - } 3 \text { questions for perceived quality of smart platform of business operator, customers and institutions, respectively } \\
\text { (e.g. In city 'A', residents and tourists can use the services through the smart platforms) }\end{array}$ \\
\hline $\begin{array}{l}\text { Smart service } \\
\text { technology }\end{array}$ & - Q1: Please select every digital services you can experience in city 'A'. \\
\hline $\begin{array}{c}\text { Life and tourism } \\
\text { environments }\end{array}$ & $\begin{array}{l}\text { - Level of traffic congestion } \\
\text { - Q1: In city 'A', tourists can easily see traffic congestion information signs.) } \\
\text { - } 2 \text { environmental indicators (level of air pollution, environmental index of CES) } \\
\text { Crime rate }\end{array}$ \\
\hline $\begin{array}{c}\text { Tourism creativity and } \\
\text { innovativeness }\end{array}$ & $\begin{array}{l}\text { Number of start-up tourism companies } \\
\text { Number of top universities in the field of hotel tourism }\end{array}$ \\
\hline Tourism safety & $\begin{array}{l}\text { - Real time surveillance and reporting } \\
\text { - } 2 \text { questions for tourists' perceived quality of tourism safety (e.g. In city 'A', tourists can safely tour in terms of } \\
\text { hygiene and security) }\end{array}$ \\
\hline City resilience & \begin{tabular}{|l|} 
- Urbanization rate \\
- Inherent cyber risk \\
\end{tabular} \\
\hline $\begin{array}{c}\text { Resident-Tourist } \\
\text { Symbiosis }\end{array}$ & Number of tourists compared to the number of residents \\
\hline Living lab activation & $\begin{array}{l}\text { - } 5 \text { questions for experts perceived quality of living lab activation (e.g. City A has manpower (e.g. facilitators) } \\
\text { and educational methods to help resolving confusion or conflict in the participation process.) }\end{array}$ \\
\hline $\begin{array}{c}\begin{array}{c}\text { Smart tourism } \\
\text { governance }\end{array} \\
\end{array}$ & $\begin{array}{l}\text { - } 5 \text { questions for experts' perceived quality of smart tourism governance (e.g. In city ' } \mathrm{A} \text { ', strategies and norms for } \\
\text { participation of the private sector related to smart tourism are shared) }\end{array}$ \\
\hline
\end{tabular}

Fig. 2. Smart tourism cities' competitiveness index

\section{Discussion and Implications}

This study suggests smart tourism cities' competitiveness index. Through literature reviews, we proposed our conceptual model based on $[2,11]$. In our conceptual model, we believe that we can be able to understand mutual aspects of smart tourism and urban cities as one 'smart tourism cities' and give a guideline for strengthening competitiveness index inclusive tourism context and urban cities. So, we provide a framework, dimensions, measurement indicators on the systematic flow and integration among smart tourism technologies and other components of destination competitiveness. With this index, we can expect to be able to diagnose the level of smart tourism in urban cities and measure their competitiveness in the future.

\section{References}

1. Koo C, Park J, Lee JN (2017) Smart tourism: traveler, business, and organizational perspectives. Inf Manag 54(6):683-686

2. Gretzel U, Sigala M, Xiang Z, Koo C (2015) Smart tourism: foundations and developments. Electron Markets 25(3):179-188 
3. Gretzel U, Werthner H, Koo C, Lamsfus C (2015) Conceptual foundations for understanding smart tourism ecosystems. Comput Hum Behav 50:558-563

4. Gretzel U, Zhong L, Koo C, Boes K, Buhalis D, Inversini A (2016) Smart tourism destinations: ecosystems for tourism destination competitiveness. Int J Tour Cities 2(2):108124

5. Koo C, Mendes Filho L, Buhalis D (2019) Smart tourism and competitive advantage for stakeholders. Tour Rev 74(1):1-128

6. Isi lab (2017) Smart City Index Report. http://isi-en.yonsei.ac.kr/download/2017-smart-cityindex-report/. Accessed 28 Oct 2020

7. Hollands RG (2008) Will the real smart city please stand up? Intelligent, progressive or entrepreneurial? City 12(3):303-320

8. Celino I, Kotoulas S (2013) Smart cities. IEEE Internet Comput 17(6):8-11

9. Lee P, Hunter WC, Chung N (2020) Smart tourism city: developments and transformations. Sustainability 12(10):3958

10. World Economic Forum (WEF): The Travel \& Tourism Competitiveness Report 2019: Travel and Tourism at a Tipping Point. https://www.weforum.org/reports/the-travel-tourismcompetitiveness-report-2019. Accessed 28 Oct 2020

11. European Union (EU) Compendium of Best Practices: 2019 European Capital of Smart Tourism competition. https://smarttourismcapital.eu/. Accessed 28 Oct 2020

Open Access This chapter is licensed under the terms of the Creative Commons Attribution 4.0 International License (http://creativecommons.org/licenses/by/4.0/), which permits use, sharing, adaptation, distribution and reproduction in any medium or format, as long as you give appropriate credit to the original author(s) and the source, provide a link to the Creative Commons license and indicate if changes were made.

The images or other third party material in this chapter are included in the chapter's Creative Commons license, unless indicated otherwise in a credit line to the material. If material is not included in the chapter's Creative Commons license and your intended use is not permitted by statutory regulation or exceeds the permitted use, you will need to obtain permission directly from the copyright holder. 